\title{
Analysis of worldwide Portland Cement Market Size and Their Properties
}

\author{
Prof. Barry Wiling \\ Professor, Department of Computer Science, \\ U.S.M.N Oman \\ barrywiling@usmn.edu
}

\section{Abstract}

Portland cement concrete that's Portland cement when combined with water, hardens into a solid mass. qualitative analysis of cement raw materials gave knowledge into the substance properties of cement. during this paper we are discussing about the varied chemical composition and properties of hydraulic cement. during this paper we also are discussing about the market size of hydraulic cement and application of cement and their ratio.

Keywords: Silica, Lime, fineness. gypsum etc.

\section{INTRODUCTION}

Portland concrete is an essential component of concrete. Portland solid makes a paste with water that attaches with sand and rock to hardento structure a strong. These solid has a substance formation of calcium, silicon, aluminum, iron and various fixings. Non-water fueled cements , and pressure driven cement are 2 noteworthy classes of progress concrete. Non-pressure driven cement doesn't set in wet conditions or lowered. Weight driven cements set and become stick due to a manufactured reaction between the dry fixings and water.

Non-hydraulic cements e.g.

(i) Plaster of Paris $\left(\mathrm{CaSO}_{4} \cdot 1 / 2{ }_{2} \mathrm{H}_{2} \mathrm{O}\right)$

$\mathrm{CaSO}_{4} \cdot 1 / 2 \mathrm{H}_{2} \mathrm{O}+1 \frac{1}{2} \mathrm{H}_{2} \mathrm{O} \Rightarrow \mathrm{CaSO}_{4} \cdot 2 \mathrm{H}_{2} \mathrm{O}$ (gypsum)

(ii) lime-based cement $(\mathrm{CaO})$

$\mathrm{CaO}+\mathrm{H}_{2} \mathrm{O} \Rightarrow \mathrm{Ca}(\mathrm{OH})_{2}+\mathrm{CO}_{2} \rightarrow \mathrm{CaCO}_{3}$ (calcite)

\section{PORTLAND CEMENT CHEMICAL COMPOUNDS OF PORTLAND CEMENT}


It is create by finely ground limestone and finely divided clay to give a burned product containing 65-70\% $\mathrm{CaO}, 18-24 \% \mathrm{SiO}_{2}, 3-8 \% \mathrm{Fe}_{2} \mathrm{O}_{3}, 3-8 \% \mathrm{Al}_{2} \mathrm{O}_{3}$ with some others $\mathrm{Na}_{2} \mathrm{O}, \mathrm{K}_{2} \mathrm{O}$, $\mathrm{MgO}$, etc. Present day plants grant considerably more proficient handling and moreover, proportion raw mix compositions to create a cement from which a range of strength development and robustness properties can be expected. Effective crushing and mixing of raw materials is fundamental.

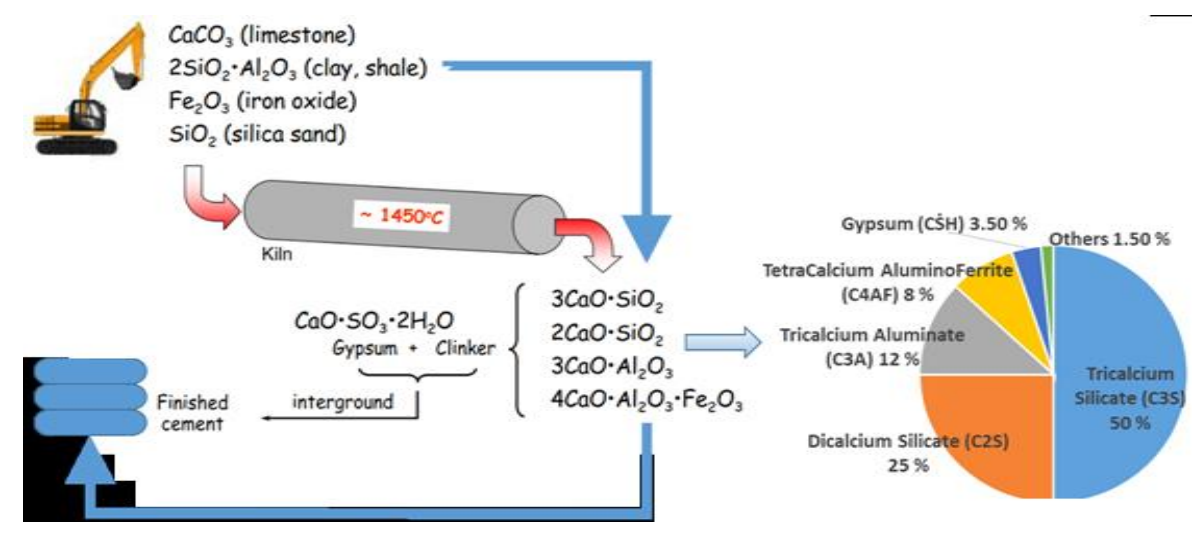

Fig 1 Portland Cement manufacturing

This table shows the chemical compounds of Portland cement, its formula and properties of this compound with weight.

TABLE 1

CHEMICAL COMPOUNDS OF PORTLAND CEMENT 


\begin{tabular}{|c|c|c|c|c|}
\hline Compound & Formula & $\begin{array}{l}\text { Shorthand } \\
\text { form }\end{array}$ & $\begin{array}{l}\% \text { by } \\
\text { weight }\end{array}$ & Properties of cement compounds \\
\hline $\begin{array}{l}\text { Alite or tricalcium } \\
\text { silicate }\end{array}$ & $\mathrm{Ca}_{3} \mathrm{SiO}_{4}$ & $\mathrm{C}_{3} \mathrm{~S}$ & $50-70 \%$ & $\begin{array}{l}\text { - It is responsible for early strength } \\
\text { - } \text { First } 7 \text { days strength is due to C3S } \\
\text { - It produces more heat of hydration } \\
\text { - Cement with more C3S is better for cold weather } \\
\text { concreting. }\end{array}$ \\
\hline $\begin{array}{l}\text { Belite or } \\
\text { dicalcium silicate }\end{array}$ & $\mathrm{Ca}_{2} \mathrm{SiO}_{5}$ & $\mathrm{C}_{2} \mathrm{~S}$ & $15-30 \%$ & $\begin{array}{l}\text { - C2S hydrates after } 7 \text { days. Hence, it gives strength } \\
\text { after } 7 \text { days. } \\
\text { - } \mathrm{C} 2 \mathrm{~S} \text { hydrates and harden slowly and provides much } \\
\text { of the ultimate strength } \\
\text { - It produces less heat of hydration. } \\
\text { - Responsible for long term strength }\end{array}$ \\
\hline $\begin{array}{l}\text { Tricalcium } \\
\text { aluminate }\end{array}$ & $\mathrm{Ca}_{3} \mathrm{Al}_{2} \mathrm{O}_{6}$ & $\mathrm{C}_{3} \mathrm{~A}$ & $5-10 \%$ & $\begin{array}{l}\text { - The reaction of C3A with water is very fast and may } \\
\text { lead to an immediate stiffening of paste, and this } \\
\text { process is termed as flash set. } \\
\text { - To prevent this flash set, } 2 \text { to } 3 \% \text { gypsum is added } \\
\text { at the time of grinding the cement clinkers. } \\
\text { - C3A liberates a lot of heat during the early stages } \\
\text { of hydration, but has little (almost none) strength } \\
\text { contribution. } \\
\text { - Cement low in C3A is sulfate resistant. }\end{array}$ \\
\hline $\begin{array}{l}\text { Tetracalcium } \\
\text { aluminoferrite }\end{array}$ & $\mathrm{Ca}_{4} \mathrm{Al}_{2} \mathrm{Fe}_{2} \mathrm{O}_{10}$ & C4AF & $5-15 \%$ & $\begin{array}{l}\text { - It hydrates very rapidly. } \\
\text { - Contributes very little strength of concrete even } \\
\text { though } \\
\text { - Also responsible for grey colour of Ordinary } \\
\text { Portland Cement } \\
\text { - The hydrates of C4AF show a comparatively higher } \\
\text { resistance to sulphate attaches than the hydrates } \\
\text { of C3A }\end{array}$ \\
\hline Sodium oxide & $\mathrm{Na}_{2} \mathrm{O}$ & $\mathrm{N}$ & \multirow{2}{*}{$\begin{array}{l}0.5- \\
1.3 \% \\
\end{array}$} & \\
\hline Potassium oxide & $\mathrm{K}_{2} \mathrm{O}$ & $\mathrm{K}$ & & \\
\hline Gypsum & $\mathrm{CaSO}_{4} \cdot 2 \mathrm{H}_{2} \mathrm{O}$ & $\mathrm{CSH}_{2}$ & & \\
\hline
\end{tabular}

The graph 2 shows the market size of Portland cement and other from 2014 to expected 2015. Fig 3 shows the application of cement and their ratio.

\section{ANALYSIS OF GLOBAL PORTLAND CEMENT MARKET SIZE AND SHARE}

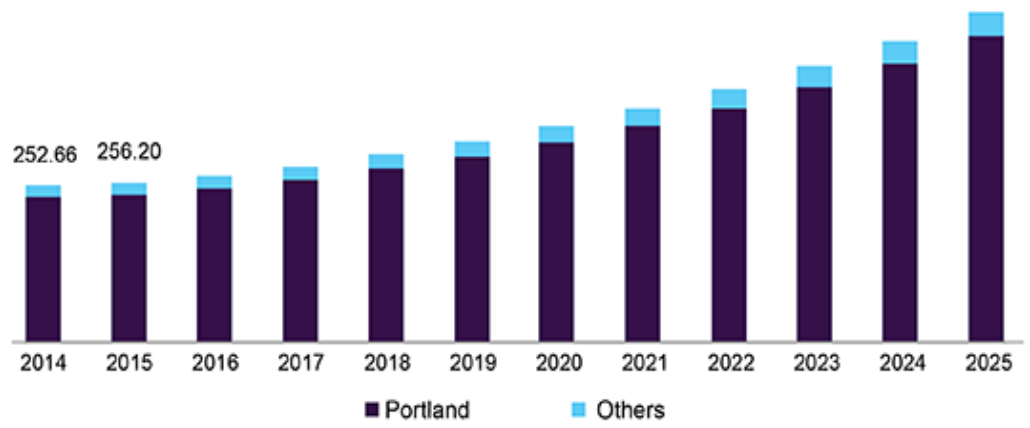

Fig 2 Cement market size 


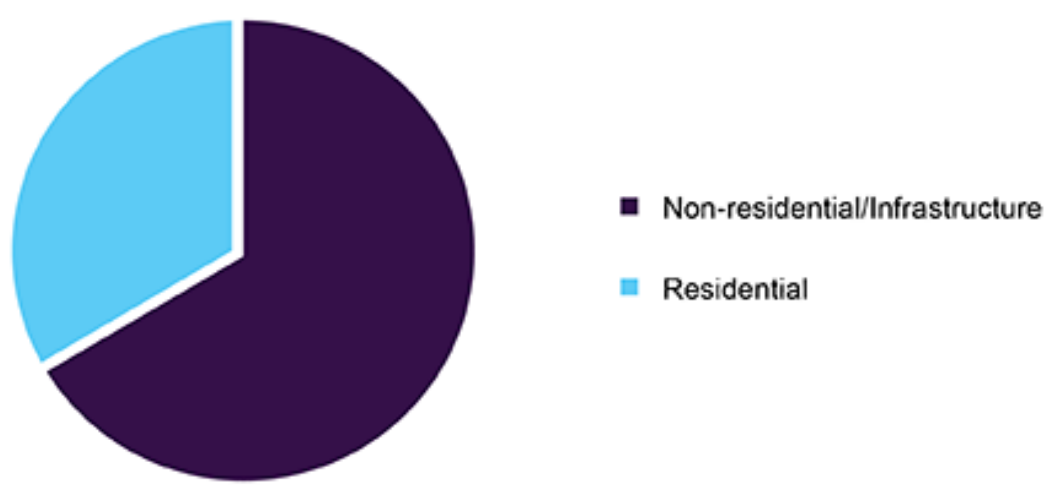

Fig 3 Global cement market share

\section{CONCLUSION}

Portland cement is used in worldwide. In this paper we have discussed about the various chemical composition and properties of Portland cement. In this paper we have also discussed about the market size of Portland cement and application of cement and their ratio.

\section{REFERENCES}

[1] C. M. Hanson, "Concrete: the advanced industrial material of the 21st century," Metallurgical \& Materials Transactions A, vol. 26, pp. 1321-1341, 1995.

[2] M. Bediako, S. K. Y. Gawu, and A. A. Adjaottor, "Suitability of some Ghanaian mineral admixtures for masonry mortar formulation," Construction and Building Materials, vol. 29, pp. 667-671, 2012.

[3] S. H. Kosmatka, B. Kerkhoff, and W. C. Panarese, Design and Control of Concrete Mixtures, Portland Cement Association,Skokie, Ill, USA, 14th edition, 2002.

[4] M. S. Mamlouk and J. P. Zaniewski, Materials for Civil andConstruction Engineers, Prentice Hall, Upper Saddle River, NJ,USA, 2006.

[5] T. Punmatharith, M. Rachakornkij, A. Imyim, and M.Wecharatana, "Co-processing of grinding sludge as alternative raw material in portland cement clinker production," Journal of Applied Sciences, vol. 10, no. 15, pp. 1525-1535, 2010.

[6] D. N. Huntzinger and T. D. Eatmon, "A life-cycle assessment of Portland cement manufacturing: comparing the traditional process with alternative technologies," Journal of Cleaner Production, vol. 17, no. 7, pp. 668-675, 2009.

[7] F. M. Lea, The Chemistry of Cement and Concrete, Arnold Publishers, London, UK, 3rd edition, 1970.

[8] J. F. Young, S.Mindess, R. J. Gray, andA. Bentur,TheScience andTechnology of Civil Engineering Materials, Prentice-Hall, Upper Saddle River, NJ, USA, 1998.

[9] H. F. W. Taylor, Cement Chemistry, Thomas Telford, London,UK, 2nd edition, 1997.

[10] S. H. Kosmatka and M. L. Wilson, Design and Control of Concrete Mixtures, Portland Cement Association, Stokie, Ill, USA, 2011. 
[11] V. Sata, C. Jaturapitakkul, and K. Kiattikomol, "Influence of pozzolan from various by-product materials on mechanical properties of high-strength concrete," Construction and BuildingMaterials, vol. 21, no. 7, pp. 1589-1598, 2007.

[12] A. Neville, Neville on Concrete, ACI, Farmington Hills, Mich, USA, 2003.

[13] R. Fernandez, F. Martirena, and K. L. Scrivener, "The origin of the pozzolanic activity of calcined clay minerals: a comparison between kaolinite, illite and montmorillonite," Cement and Concrete Research, vol. 41, no. 1, pp. 113-122, 2011.

[14] K. Ganesan, K. Rajagopal, and K. Thangavel, "Evaluation of bagasse ash as supplementary cementitious material," Cement and Concrete Composites, vol. 29, no. 6, pp. 515-524, 2007.

[15] S. Sinthaworn and P. Nimityongskul, "Quick monitoring of pozzolanic reactivity of waste ashes," Waste Management, vol.29, no. 5, pp. 1526-1531, 2009.

[16] J. J. Brooks,M. A.M. Johari, andM.Mazloom, "Effect of admixtures on the setting times of highstrength concrete," Cement and Concrete Composites, vol. 22, no. 4, pp. 293-301, 2000.

[17] X. Fu, Z.Wang,W. Tao et al., "Studies on blended cement with a large amount of fly ash," Cement and Concrete Research, vol. 32,no. 7, pp. 1153-1159, 2002.

[18] E.-H. Kadri, S. Kenai, K. Ezziane, R. Siddique, and G. De Schutter, "Influence of metakaolin and silica fume on the heat of hydration and compressive strength development of mortar," Applied Clay Science, vol. 53, no. 4, pp. 704-708, 2011.

[19] V. Indrawati and A. Manaf, "Mechanical strength of trass as supplementary cementing material," Journal of Physical Science, vol. 92, no. 2, pp. 51-59, 2008. 